\begin{tabular}{l} 
KONSTAN \\
JURNAL FISIKA DAN PENDIDIKAN FISIKA \\
Volume 4, Nomor 1, Juni 2019 \\
$\begin{array}{r}\text { E-ISSN : } 2460-9129 \text { dan P-ISSN }: 2460-9110 \\
\text { http://jurnalkonstan.ac.id/index.php/jurnal }\end{array}$ \\
\hline
\end{tabular}

\title{
PENGARUH FLOURIDE TERHADAP SIFAT MEKANIK GIGI TIRUAN BERBAHAN DASAR LIMBAH CANGKANG TELUR AYAM
}

\author{
Baiq R. S. Yusuf ${ }^{1}$, Siti Alaa ${ }^{1 *}$, Dian W. Kurniawidi ${ }^{1}$, Susi Rahayu ${ }^{1}$ \\ ${ }^{1)}$ Program Studi Fisika, Universitas Mataram, Jl. Majapahit no. 62. Mataram, NTB, \\ Indonesia
}

\section{Info Artikel}

Sejarah Artikel:

Diterima Mei 2019

Disetujui Juni 2019

Dipublikasikan Juni 2019

\section{Kata Kunci:}

Flouride, gigi tiruan, cangkang telur, sifat mekanik.

\begin{abstract}
Abstrak
Pembuatan gigi tiruan dari cangkang telur telah dilakukan dilakukan dengan menggunakan metode presipitasi. Pengujian FTIR dan AAS dilakukan untuk mengetahui gugus fungsi dan kandungan kalsium oksida pada cangkang telur. Dari hasil AAS diperoleh nilai $\mathrm{CaO}$ sebesar 58,33\% yang jauh lebih besar dari standar minimal $\mathrm{CaO}$ pada gigi tiruan. Uji mekanik dilakukan pada perlakuan gigi tiruan dengan perendaman aquades dan hasilnya dibandingkan jika perendaman dengan menggunakan pasta gigi berflouride. Didapatkan bahwa perendaman dengan pasta gigi berflouride dapat meningkatkan elastisitas gigi tiruan hingga lebih dari $100 \%$.
\end{abstract}

(C) 2019 Universitas Islam Negeri Mataram

* Corresponding Author: siti.alaa@unram.ac.id

Alamat korespodensi:

Gedung Pasca Sarjana Lantai 3 Kampus 2 UIN Mataram, Jl. Gajah Mada 100 Jempong Mataram, Indonesia

Email: jurnalkonstan@uinmataram.ac.id 


\section{PENDAHULUAN}

Biokeramik merupakan material implant yang sangat dikenal dan banyak digunakan untuk perbaikan, pergantian dan penambahan jaringan tulang dan gigi. Salah satu biokeramik yang terkenal dan sering digunakan dalam bidang rehabilitasi jaringan tulang dan gigi adalah yang mengandung kalsium tinggi [1]. Menurut Hench [2], sumber kalsium tertinggi yang dapat digunakan sebagai bahan biokeramik terdapat pada tulang ikan, cangkang kerang hingga cangkang telur ayam. Pada umumnya cangkang telur ayam yang baik kandungan kalsiumnya setelah mengalami proses kalsinasi adalah cangkang telur ayam ras.

Kadar oksida yang baik menunjukkan jumlah kalsium tinggi [3]. Kalsium tinggi pada cangkang telur dapat digunakan dalam pengembangan teknologi ilmu kedokteran untuk pembuatan gigi tiruan yang kuat. Untuk memperoleh kandungan kalsium yang tinggi, cangkang telur ayam dapat direaksikan dengan beberapa senyawa [4]. Senyawa akan menambahkan mutu dari cangkang telur ayam agar dapat dimanfaatkan lebih baik dibandingkan dengan menjadikan cangkang telur sebagai limbah tak terpakai.

Kualitas dari gigi dapat dijaga dengan cara melakukan perawatan rutin seperti menggosok gigi menggunakan pasta gigi [5]. Untuk mengetahui adanya pengaruh dari pasta gigi terhadap gigi tiruan terutama pada kekerasan dan kuat tekannya perlu dilakukan pengujian dari sifat mekaniknya. Maka dari itu pada penelitian ini dilakukan pengujian sifat mekanik khususnya modulus elastis gigi tiruan setelah perendaman pada pasta gigi berflouride.

\section{METODE PENELITIAN}

Metode presipitasi dilakukan untuk mendapatkan bahan gigi tiruan [6]. Kandungan kalsium oksida didapatkan setelah cangkang telur mengalami proses kalsinasi, dimana proses kalsinasi bertujuan untuk membuang karbon dalam bentuk karbon dioksida dari kalsium karbonat. Proses kalsinasi dilakukan menggunakan furnace pada suhu $900{ }^{\circ} \mathrm{C}$ selama 4 jam. Dari hasil kalsinasi didapatkan serbuk putih dengan terdapat sedikit warna kekuningan yang disumbangkan oleh gugus PO seperti pada Gambar 1a.

Limbah cangkang telur yang telah diolah diuji gugus kimianya menggunakan Fourier Transform Infrared Spectroscopy (FTIR) dan besarnya persentase kandungan kalsium oksida cangkang telur diukur menggunakan metode Anatomic Absorption Spectrophotometer (AAS).

Serbuk putih tersebut ditambahkan dengan aquades dengan perbandingan 6 gr sebuk dan 5 tetes aquades. Kemudian Sampel gigi tiruan dicetak menggunakan cetakan manual dengan ukuran sampel $10 \mathrm{~mm}$ x $10 \mathrm{~mm}$ x $10 \mathrm{~mm}$ lalu dikeringkan pada suhu kamar $\left(25{ }^{\circ} \mathrm{C}\right)$ selama $12 \mathrm{jam}$. Sampel yang telah dikeringkan akan mengeras dikarenakan oleh lepasnya kandungan mineral ke udara.

Perendaman sampel gigi tiruan dibedakan menjadi dua kelompok, yaitu kelompok kontrol dan kelompok perlakuan. Sampel terdiri dari dua jenis yaitu sampel yang direndam dalam larutan aquades (S1) dan sampel yang direndam dalam pasta gigi berflouride (S2). Perendaman dilakukan dengan variasi lama 
perendaman yaitu pada perendaman 6 jam untuk estimasi perawatan selama 3 bulan, 12 jam untuk estimasi perawatan selama 6 bulan dan 24 jam untuk estimasi perawatan selama 12 bulan. Lama perendaman di sesuaikan dengan lamanya waktu perawatan gigi setiap hari. Pada tiap-tiap kelompok dilakukan tiga kali pengulangan sebagai pembanding untuk setiap variasi waktu perendaman.

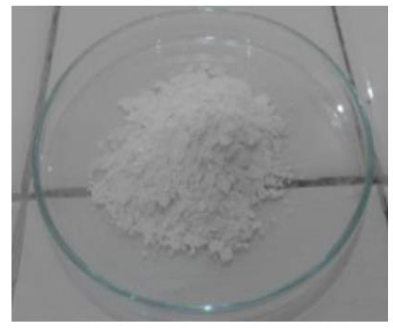

(a)

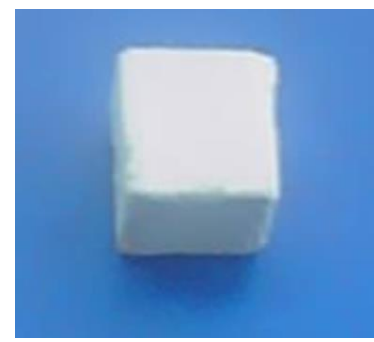

(b)

Gambar 1 a) Serbuk cangkang telur setelah presipitasi. b) sampel gigi tiruan yang telah dicetak

Pengujian sifat mekanik dilakukan menggunakan Tensile Machine RTG1310 dimana seluruh sampel akan diberikan tekanan penuh oleh alat secara perlahan demi menemukan titik retak pada sampel untuk mengetahui kekuatan sampel dari tekanan. Pengujian tekan dilakukan dengan tekanan sebesar $10.000 \mathrm{~N}$ dengan kecepatan $0,5 \mathrm{~mm} / \mathrm{min}$. Titik retak (break point) yang terjadi pada sampel terjadi hingga lebih 5 kali untuk menghancurkan sampel.

\section{HASIL DAN PEMBAHASAN}

Uji FTIR dilakukan untuk mendapatkan spektrum transmitansi sampel cangkang telur yang telah dikalsinasi. Terlihat pada Gambar 2. bahwa terdapat puncak-puncak pada bilangan gelombang (wave number) 3444,33-3643,2 cm-1 yang merupakan karakteristik mode peregangan (stretching mode) gugus $\mathrm{OH}$, sedangkan serapan pada bilangan gelombang 1449,22-1650 cm-1 memperlihatkan mode lentur (bending mode) gugus karbonat (CO-), dan serapan pada bilangan gelombang 1063,86 cm-1 yang merupakan gugus fosfat (PO4-). Nampak bahwa gugus fosfat terdeteksi paling dominan. Hasil ini menunjukkan tingkat kemurnian cangkang telur sebagai bahan dasar penyusun gigi dengan kandungan kalsium yang sangat tinggi, walaupun masih terdapat gugus karbonat dalam jumlah yang lebih besar dibandingkan $\mathrm{OH}$. Sehingga cangkang telur layak digunakan sebagai bahan gigi tiruan.

Dari hasil AAS, berdasarkan perbandingan jumlah kadar oksida dapat diketahui kadar senyawa kalsium oksida dari cangkang telur sebesar 58,33\%. Jumlah persentase tersebut dapat dijadikan sebagai bahan utama pembuatan hidroksiapatit karena kandungannya mendekati standar yaitu 61,60\% dan melewati setengah dari standar yaitu 30,80\% [7].

Dari hasil uji mekanik menggunakan Tensile Machine, tekan terjadi break point (titik hancur) pada sampel yang diperlihatkan oleh garis berwarna biru (Gambar 3). Titik hancur yang terjadi lebih dari satu kali untuk seluruh sampel agar sampel hancur secara maksimal. Data yang dianalisis pada penelitian ini adalah data 
titik hancur yang terjadi pertama kali pada sampel serat nilai tegangan dan regangannya. Break point sampel pertama terjadi saat pembebanan sebesar $30 \mathrm{~N}$ dengan skala perpindahan sebesar $0,150 \mathrm{~mm}$. Skala perpindahan adalah perubahan panjang yang terjadi pada sampel setelah pembebanan. Dari pembebanan dan perubahan panjang dapat diketahui nilai tegangan dan regangan maksimal yang diterima sampel.

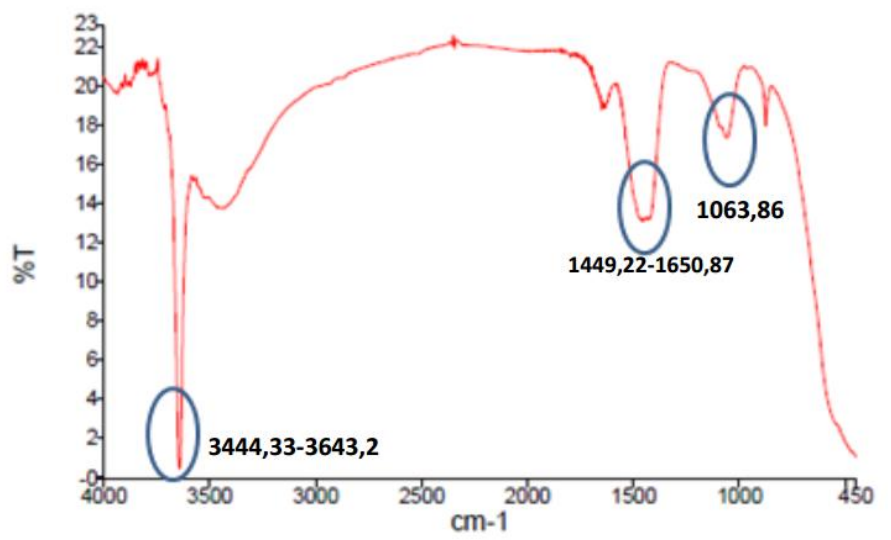

Gambar 2 Spektra infra red (FTIR) cangkang telur yang dimurnikan dengan metode presipitasi.

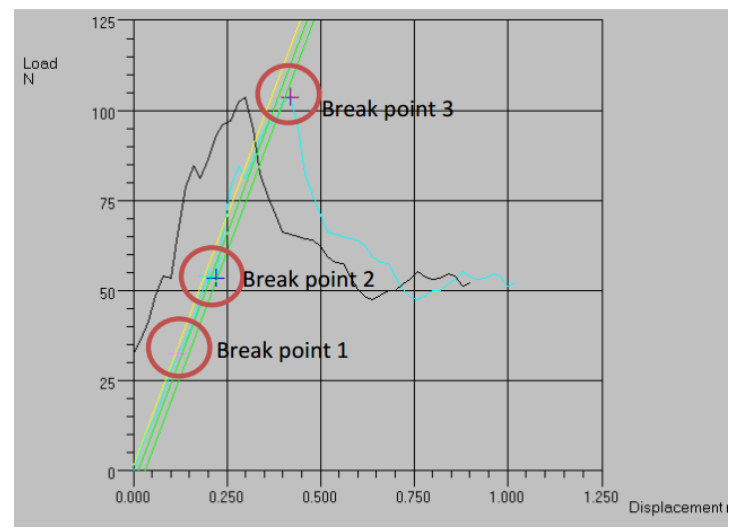

Gambar 3 Grafik hubungan load dan elongation sampel perendaman pertama

Dari hasil pengukuran modulus elastis, didapatkan bahwa perendaman pada pasta gigi berflouride dapat meningkatkan modulus elastis gigi hingga lebih dari $100 \%$. Semakin lama flouride digunakan, modulus elastis akan semakin meningkat, namun pemakaian yang terlalu lama juga akan menyebabkan kerusakan gigi atau penuruan kualitas gigi (modulus elastis menurun). Pasta gigi yang mengandung fluoride mampu meningkatkan kualitas dari gigi tiruan lebih baik di bandingkan dengan yang tidak mengandung fluoride. Selain itu kuat tekan yang diterima oleh 
sampel setelah mengalami perendaman pada pasta gigi berflouride lebih baik daripada sampel yang direndam dengan aquades.

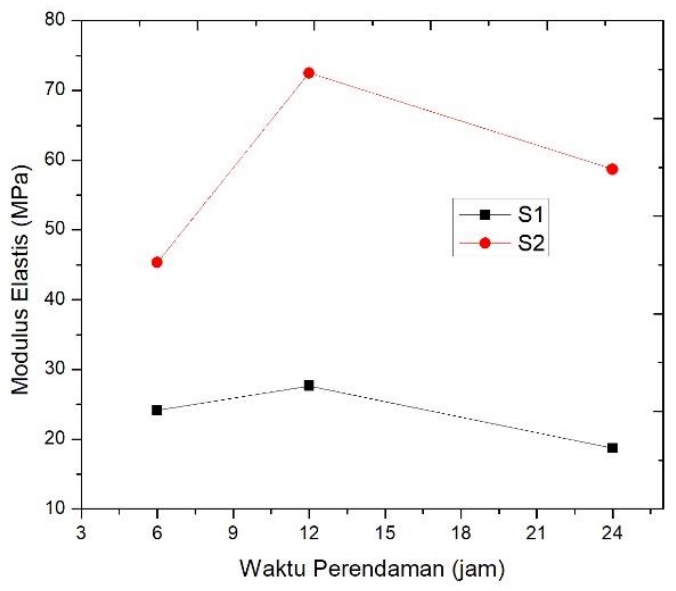

Gambar 4. Grafik hubungan antara waktu perendaman dengan modulus elastis gigi tiruan.

\section{SIMPULAN DAN SARAN}

Berdasarkan penelitian yang telah dilakukan dapat diambil kesimpulan bahwa kandugan senyawa kalsium oksida dari cangkang telur sebesar 58,33\%. Jumlah persentase tersebut dapat dijadikan sebagai bahan utama pembuatan hidroksiapat karena kandungannya mendekati standar yaitu 61,60\% dan melewati setengah dari standar yaitu $30,80 \%$. Kualitas dari gigi tiruan lebih baik pada perendaman dengan pasta gigi berflouride dibandingkan dengan yang direndam dengan aquades. Jadi, perendaman pada pasta gigi sebagai metode perawatan gigi tiruan dapat diaplikasikan pada kegiatan sehari-hari meskipun kekuatannya akan sedikit terpengaruhi untuk jangka waktu yang lama.

Saran untuk penelitian selanjutnya adalah perlu adanya tambahan penguat/perekat sebagai matriks tambahan pada sampel gigi tiruan agar mampu meningkatkan kekuatan gigi tiruan ketika diberikan beban yang lebih besar.

\section{DAFTAR PUSTAKA}

[1] Setiawan, Dendi Catur. 2013. Analisis Sifat Fisis dan Mekanis Bahan Biokeramik Hydroxiapatite Padat dari Bahan Baku Alami. Yogyakarta : Universitas Gadjah Mada.

[2] Hench, L, L, 1991. Bioceramics: Form Concept to Clinic. Journal of the American Ceramic Society, volume 74, nomor 7 hal 1487-1510

[3] Ihfa, Indira Nurnaifah Idris. 2012. Pembuatan Gigi Tiruan Berbasis Bahan Porselen dan Pengujian Sifat Fisisnya. Makasar. Fakultas MIPA Jurusan Fisika Universitas Hasanuddin. 
[4] Suhaneck, W. dan Yoshimura M. 1998. Processing and Properties of Hydroxyapatite-Based Biomaterials for Use as Hard Tissue Replacement Implants. Amerika serikat : Harvard university.

[5] Senjaya, Asep Arifin. 2013. Menyikat Gigi Tindakan Utama Untuk Kesehatan Gigi. Jurnal Skala Husana volume 10 nomor 2 hal 194-199

[6] Wadu, Imelda., Soetjipto, Hartati dan Cahyanti, Margareta Novian. 2018. Sintesa dan Penentuan Kadar Kalsium-Fosfat Hidroksiapatit (HAp) Dari Kerabang Telur Ayam. JKPK (Jurnal Kimia dan Pendidikan Kimia), volume 3, nomor 1 hal 1-5.

[7] Rauf, Nurlaela., Suryani, Sri., Suarni, Hendrik, dan Saputra, Sidik. 2013. Pengaruh Komposisi Bahan Terhadap Kekerasan Gigi Tiruan Berbasis Keramik. Prosiding SNF-MKS. 